\title{
THE IMPACT OF THE ELECTRONIC CULTURE ON ETHICS AND MANAGERIAL CULTURE
}

\author{
Jucan Cornel Nicolae ${ }^{1}$ \\ Jucan Mihaela Sabina ${ }^{2}$
}

\begin{abstract}
This paper undertakes to investigate the rich documentary material which has put forth or suggested that the improvement process of corporate practices continues and that there are more and more companies, firms, etc. and even countries interested in understanding and implementing these principles. This interest stems from these entities' desire to become reliable partners for the countries with tradition in the field, which in time will lead to an increasing alignment of different cultures in the field of corporate governance. The opening of the markets, globalization, the access to advanced technology, determine new forms of ethics. These new forms of ethics, as well as the ethical management tools, ethical standards, codes of ethics, reports of corporate social responsibility or social labels related to them, generate prestige and joint stock that are in turn converted into opportunities for sustainable development and long-term profit. In addition, the widespread use of the computer began to substantially modify the management decisions and to shape the organizational culture along new directions of electronic culture. The concept of "electronic culture" refers to the organizational culture that forms within a community. This community widely uses the computer as an important tool in the process of intra-and extraorganizational communication, as well as the basis for decisions and actions of its constituents, influencing the major attitudes, behavior and performance of its members.
\end{abstract}

Key words: Business, Culture, Decision making, Electronics, Ethics, Globalization, Information, Management, Responsibility.

JEL codes: $A 13$

\section{Moral or ethical responsibility in business}

In the last decades, the business sphere has undergone essential changes that will affect decisively the idea of commercial enterprise. Joseph Badaracco, professor of business ethics at Harvard Business School, explains that these transformations through the closed firm versus open firm opposition (Badaracco, J., 1994).

A classic company is an autonomous and individualized organization, separated from the rest of the companies through four types of borders: financial, administrative, social and contractual. These companies rely heavily on internal financial resources, trying to reduce its dependence on external sources of capital. In such firms, the administrative structure is of a military type characterized by a hierarchical decision system and subordination between different hierarchical levels. The groups of closed companies have strong, authoritarian leaders. These groups are not constituted through affinity or moral values, but are purely formal groups, created according to business objectives. The sphere of managerial power in the closed firms is bounded also by what the economics call traditional contractual relationship, a secluded and restrictive business relationship, which requires the creation of formal, accurate, comprehensive and very

\footnotetext{
${ }^{1}$ Faculty of Economics Sciences, „Lucian Blaga” University of Sibiu, 550324 Sibiu, Calea Dumbrăvii 17, ROMANIA, cnjucan@yahoo.com

${ }^{2}$ Faculty of Economics Sciences, „Lucian Blaga” University of Sibiu, 550324 Sibiu, Calea Dumbrăvii 17, ROMANIA, cnjucan@yahoo.com
} 
detailed agreements that define the company's rights and obligations as well as those of its partners. The traditional business environment is a world regulated by the evolutionary principle of survival of the strongest through the elimination of the weakest.

To describe the modern company, John Welch, former head of General Electric Corporation, proposed the concept of business without borders.

The modern company has highly mobile and porous borders. The contemporary business world no longer understands competition in terms of a fight for survival, but of an opportunity to identify new opportunities, new forms of new types of business partnerships, innovative products and services. The modern business environment emerges as a network in which each company is aware that it can increase its opportunities of profit not by breaking rules or eliminating competitors on the market through immoral practices, but by working in collaboration with other companies and respecting rules generally accepted in the society and in the business communities. The new concepts of business environment are management orientated to the interested groups, network business, ethical management, corporate social responsibility, sustainability, social entrepreneurship, civic global corporate.

All these changes can be described in relation to one concept: moral or social responsibility in business. To a large extent, changes in modern management are determined by a single factor: the management objectives aimed not only at the investor's interests but at the interests or the socalled expectations of all interested groups, groups that may be affected by decisions made by companies or that can have a long-term influence on the evolution of companies. Thus, corporate strategies and policies include not only the short-term profit target but also the objective of sustainable development; not only the owners' or shareholders' interests, but also those of the customers and employees, communities and society as a whole; not only the legal rules imposed, but also the ethical, voluntary standards.

The sphere of responsibilities of management today is expanding, and companies seek to find profit and development opportunities precisely in these new responsibilities. Firstly, the opening of markets, globalization and increasing competition require companies to assume more and more responsibilities, providing enhanced quality, better working conditions, and social benefits to communities. Moreover, this expansion of the sphere of ethics and responsibility generates, in the long run, prestige, employee loyalty, consumer loyalty to the brand. It can therefore be stated that the market creates ethics, while companies and advanced managers find business and profit opportunities exactly in these new types of responsibilities expected from the companies.

Natalia Yakovleva (Corporate Social Responsibility in the Mining Industry, Ashgate Publishing, Ltd., 2005) outlines the history of this trend of the expansion of the sphere of responsibilities in business. The milestones Yakovleva defines bring to light the growth of ethics that modern management determines, translated into new ethical and social responsibilities put into play in the business environment (Yakovleva, N., 2005).

At the same time, these milestones in fact define the very paradigm shift in business environment today mentioned above: the shift from the traditional, closed, autonomous company, described by the metaphor of medieval castle, to the modern, open company that seeks to gain market advantages not through isolation but through interaction. New types of responsibilities obligate firms to take into account the social interactions caused by their activities.

The modern management transforms these interactions into joint stock which, in turn, generates economic opportunities through various means: public-private partnerships between companies and local communities meant to identify new business opportunities; partnerships with NGOs for research projects that lead to the development of new products and services; partnerships with universities in educational projects to prepare a qualified workforce, etc. 
The ethical dimension of the Corporate Social Responsibility (CSR) thus refers to behaviors and activities that are approved or prohibited by organization members, community, society, even though not necessarily codified by law (Jucan, C.N.; Jucan, M.S., 2010).

\section{Assumptions underlying business ethics}

In short, the free market creates ethics. New advantages of the free market, the opening of markets, globalization, access to technology, create new forms of ethics. These new forms of ethics, as well as the ethical management tools, ethical standards, ethical codes, corporate social responsibility or social labels associated with them, generate prestige and joint stock that are converted into sustainable development opportunities and long-term profit.

Given this relationship between ethics and profit, four premises of business ethics can be identified (Bishop, M., 2009).

Ethics can be seen as a theory of decision. As a philosophical discourse about morals, ethics seeks to rationalize the process through which individuals and organizations make decisions. To this end, ethics grounds the general framework for ethical reasoning (deontological ethics and Kantianism, consequentialism/ utilitarianism, contractualism, etc.), defines the basic concepts (good-bad or right-wrong, rights-debts, responsibility, utility, values, norms, ethical principles, etc.) and proposes theories that can be developed into decision-making tools, into algorithms for solving various types of moral conflicts.

Business ethics is a decision theory applied in management. Business ethics is not just an academic discipline, an opportunity for intellectual debate. It also has to do with applied ethics and management. Thus, it provides theories necessary for understanding business as an economic and social phenomenon, as well as useful tools in the decision-making process in the activity of a company.

The non-contradiction between ethics and business: ethics and businesses are not and are not based on concepts, values, anti-ethical ideas. On the contrary, ethics and business are compatible. Free market principles - private property, free exchange, the principle of freedom of contract - are compatible with the ethical principles. Businesses produce not just profit for investors, but also goods and services for consumers, working places for the community, innovation and values for the society as a whole. Therefore, businesses produce ethics.

Ethics management is a long-term profitable management. Ethics is useful to businesses, at least in so far as:

(a) it aims to rationalize and, thus, to optimize the decision-making process; and

(b) it proposes and justifies rules of conduct that guide relations among economic agents.

The ethical tools of decision-making streamline the interactions between companies and their interested groups. Therefore, ethical management can become efficient in the long term from the economical point of view (De George, R.T., 1990).

The impact of the electronic culture on ethics and managerial culture

Computers began to gain importance in the activity and life of firms and companies as early as 1950 - 1960, with the introduction by IBM of the 360 series computers. The first family of microprocessors manufactured by Intel made the computers industry face an explosive development.

As early as 1993, a research conducted in the United States showed that 45.8 percent of the workforce was already using the computer. The figure becomes even more impressive given the 
specifics of some activities in which computer - use was very low (e.g. food preparation, construction, agriculture, mining, etc.).

The electronic revolution has thus imposed a set of new conditions, such as the familiarization and creation of the necessary environment for the use of the computer and the emergence of a new labor market - that of the agents with computer skills.

The introduction of computers into all the fields of a company's activities marked substantially the intrinsic work content as well as the social relations established within the organization.

The development of some automated technological lines, in which the largest part of the workers' tasks is that of supervising a series of control panels, has led to the replacement of specific sets of skills, knowledge, and experience necessary to achieve a particular set of products with new, less numerous and less sophisticated ones. In many firms, the worker, like a physician, monitors, clicks on some buttons, and the end product, for which he/she is responsible, is produced.

A similar phenomenon occurred also at the "white collar" level, where traditional knowledge, methods and techniques, have now been replaced with knowledge of some computer processes. The managers and specialists' modes of work have changed as a result of the fact that a series of direct relations, "face-to-face" communications have been replaced with the transmission of messages over the Internet. Even the handing or receiving of information from one colleague to another - which is also an opportunity for social interaction - has been replaced by the same kind of impersonal contact.

Through their design and modes of operation, electronic systems tend to isolate the members of a community; oral communication and common actions are converted into electronic impulses and displayed in the form of drawings or text. Informal organization thus gains greater prominence, the employees' activity is enriched in new ways, but, at the same time, it is much impoverished in terms of the human dimension and basic knowledge of that activity.

There is another negative perception of the expansion of the computer use: the managements' capacity to adequately monitor and evaluate the employees. It is often difficult to rely only on a series of cold, impersonal data that you get from a microprocessor or that someone sends through a database. Employees are increasingly afraid of being under permanent surveillance as a result of the development of video and audio surveillance and of techniques of processing on the computers.

It is obvious that the era of the computer and information technology increasingly determines radical changes in the behavior and the communication patterns of employees and, implicitly, in culture.

Until a few years ago, in the "traditional" firms, the cultures were creations that offered a special - human - significance to the time spent at the firm.

The cultures contained many rituals of daily activity, reinforced by a direct, often informal, communication among its components. Routine activities were frequently interspersed with social gatherings - a means of communication and consolidation of cultural values.

The widespread use of the computer has begun to change these aspects and to shape the organizational culture along new directions - those of the electronic culture.

The electronic culture is defined as the organizational culture that forms within a community which widely uses the computer as an important extra - and intra - organizational means of communication, as well as the basis for the decisions and actions of its constituents, influencing in a major way the attitudes, behavior and performance of its members.

One of the major transformations occurred in recent years is the intellectualization of the labor and the increase in the number of specialists. This newly-constituted "white collar" layer now exceeds 50 percent of the active labor.

Work used to be mostly a social experience with occasional conflicts that arose between different parties and were settled directly by a person considered neutral, but whose informal 
authority was recognized. In this working environment, people were telling jokes, talking about diverse things during coffee breaks or lunch. This type of environment offered opportunities for the exchange of ideas.

Today, by contrast, work is more intensive, the requirements are higher, and time seems to pass more quickly. The world is constantly in a hurry, running out of time, and increasingly tied to the computer; even coffee is served in the office, while the worker is completing tasks in front of the computer. For jokes there are special sections on different sites. It thus seems that the ability and desire for direct communication of the members of a community are atrophied a cold, impersonal communication, carried out from the shelter of the screen, has come to predominate.

Without doubt, the emergence of the computer and the development of information technology offer a multiplicity of benefits to a firm. At the same time, however, in order for these advantages to be accurately and successfully delineated, the negative aspects of these changes must also be taken into account.

\section{References}

1. Badaracco, J. L., 1994. Business Ethics: Roles and Responsibilities, McGraw-Hill Professional Publishing.

2. Bishop, M., 2009. Final de epocă în afaceri, annual supplement "Lumea în 2009 - The Economist", Romanian version for Capital.

3. Crăciun, D.; Morar V.; Macoviciuc, V., 2004. Etica afacerilor, Paideia Publishing House, Bucureşti.

4. Crane, A., Matten, D., 2004, Business Ethics, A European Perspective, Oxford University Press.

5. De Goerge, R.T., 1990. Business Ethics. 3 rd Ed., Macmillan, New York.

6. Ghiță, M., Briciu, S. et all, 2009. Guvernanța corporativă şi auditul intern, Aeternitas Publishing House, Alba Iulia.

7. Hada, T.; Achim M. I., 2007. Managementul şi finanțarea afacerilor, Risoprint Publishing House, Cluj-Napoca.

8. Jucan, C. N.; Jucan, M. S., 2010. Social Responsability in Tourism and Sustainable Development. in Latest Trends on Cultural Heritage \& Tourism, 3rd WSEAS International Conference on Cultural Heritage and Tourism (CUHT"10), Corfu Island, Grece.

9. Solomon, C. R., 1994. Morality and the Good Life, New York, McGraw - Hill Professional Publishing.

10. Silbiger, S., 1999. MBA în zece zile: ce se învață la cele mai bune universităţi americane, Andreco Publishing House.

11. Yakovleva, N., 2005. Corporate Social Responsibility in the Mining Industry, Ashgate Publishing, Ltd.

12. Yanping Zhao, YidanWang, Donghua Zhu, 2005. A New Approach Towards Intelligent Analysis for Competitive Intelligence in Entreprise. Proceedings of 5thWSEAS International Conference on: Information Science, Communications and Applications (ISCA2005), Cancun, Mexico.

13. Ziglar Zig, 2002. Arta vânzării, Amaltea Publishing House, Bucureşti. 